\title{
Pengaruh pH dan Suhu terhadap Aktivitas Pereduksi Merkuri Bakteri Resisten Merkuri Tinggi Bacillus cereus yang Diisolasi dari Urin Pasien dengan Amalgam Gigi
}

\section{Billy J. Kepel, Widdhi Bodhi, Fatimawali}

Bagian Kimia Fakultas Kedokteran Universitas Sam Ratulangi Manado

E-mail: billyjohnsonkepel@gmail.com; widdhi_bodhi@yahoo.com; fatimawali@unsrat.ac.id

\begin{abstract}
Mercury is a very toxic compound to humans, therefore, a method to overcome its presence in the environment is required. Detoxification of mercury can be done by using mercury resistant bacteria. Mercury-resistant bacteria Bacillus cereus isolate FUA have been obtained from the urine of patients with dental mercury amalgam. This study was aimed to determine the mercury detoxification activity of Bacillus cereus isolate FUA at varying $\mathrm{pH}$ medium and incubation temperature. The study was carried out by growing Bacillus cereus isolate FUA on oblique media, then were planted in the growth media of LB broth containing mercury compounds of $10 \mathrm{ppm}$ $\mathrm{HgCl}_{2}$ with varying $\mathrm{pHs}$ of 5, 7, and 9 and incubation temperatures of 15,25 and $35^{\circ} \mathrm{C}$. The amount of bacterial growth was analyzed by using spectrophotometer and mercury levels were analyzed by using CV-AAS method. The results showed that the growth and mercury reducing activity of Bacillus cereus isolate FUA were optimum at $\mathrm{pH} 7$ and incubation temperature of $35^{\circ} \mathrm{C}$. In conclusion, the growth of Bacillus cereus isolate FUA and its mercury reducing activity were optimum at $\mathrm{pH} 7$ and temperature of $35^{\circ} \mathrm{C}$. It is expected that the results of this study can be the basis for further research on the process of mercury detoxification
\end{abstract}

Keywords: Bacillus cereus, urine, mercury resistance, $\mathrm{pH}$, temperature

\begin{abstract}
Abstrak: Merkuri adalah senyawa yang sangat beracun bagi manusia sehingga diperlukan metode untuk mengatasi keberadaannya di lingkungan. Detoksifikasi merkuri dapat dilakukan dengan menggunakan bakteri resisten merkuri. Bakteri yang resisten merkuri Bacillus cereus isolat FUA telah diperoleh dari urin pasien dengan amalgam gigi. Penelitian ini bertujuan untuk mengetahui aktivitas detoksifikasi merkuri Bacillus cereus isolat FUA pada berbagai variasi $\mathrm{pH}$ medium dan suhu inkubasi. Bakteri Bacillus cereus isolat FUA ditumbuhkan pada media miring, kemudian ditanam pada media pertumbuhan bakteri LB broth yang mengandung senyawa merkuri $10 \mathrm{ppm}$ $\mathrm{HgCl}_{2}$ dengan berbagai $\mathrm{pH} 5,7$ dan 9 dan suhu inkubasi 15,25 dan $35^{\circ} \mathrm{C}$. Jumlah pertumbuhan bakteri dianalisis menggunakan spektrofotometer dan kadar merkuri dianalisis menggunakan metode CV-AAS. Hasil penelitian menunjukkan bahwa aktivitas pertumbuhan dan aktivitas pereduksi merkuri Bacillus cereus isolat FUA optimum pada lingkungan pertumbuhan dengan $\mathrm{pH}$ 7 dan suhu inkubasi $35^{\circ} \mathrm{C}$. Simpulan penelitian ini ialah aktivitas pertumbuhan dan pereduksi merkuri Bacillus cereus isolat FUA yang optimum pada $\mathrm{pH} 7$ dan suhu $35^{\circ} \mathrm{C}$. Diharapkan hasil penelitian ini dapat menjadi dasar untuk penelitian lebih lanjut tentang proses detoksifikasi merkuri.
\end{abstract}

Kata kunci: Bacillus cereus, urin, resistensi merkuri, $\mathrm{pH}$, suhu

\section{PENDAHULUAN}

Sumber daya alam merupakan salah satu tulang punggung pendapatan negara dan juga pendapatan langsung masyarakat. Hal ini membuat lingkungan alam banyak dieksploitasi, misalnya untuk mendapatkan emas sebagai sumber penghasilan. Eksploitasi emas ini tidak hanya dapat membawa manfaat langsung kepada masyarakat dalam bentuk penambangan emas masyarakat, 
tetapi kadang-kadang dapat merugikan karena kegiatan yang tidak terkendali. Masyarakat mengeksploitasi lingkungan dengan hanya mendapatkan emas yang diinginkan tetapi dengan mengorbankan aspek kesehatan lingkungan, misalnya penggunaan merkuri dalam proses penggabungan emas. Hasil limbah merkuri dari pengolahan penambangan emas masyarakat diproses secara sederhana yang hanya berakhir pada pembuangan limbah lingkungan. Pelepasan limbah merkuri ke lingkungan akan mencemari tanah dan air yang merupakan sumber mata pencaharian dan akan berdampak pada kesehatan manusia.

Merkuri adalah unsur yang sangat beracun meskipun sangat sedikit konsentrasi dalam tubuh. Meskipun semua bentuk kimiawi merkuri beracun, perhatian kesehatan masyarakat difokuskan pada merkuri organik yang merupakan bentuk merkuri paling beracun. Siklus biogeokimia merkuri di lingkungan berperan dalam mengatur toksisitas merkuri, di mana proses metilasi ion merkuri $\left(\mathrm{Hg}^{2+}\right)$ secara langsung atau tidak langsung atau degradasi metilmerkuri ialah kunci penting untuk toksisitas merkuri, baik dalam mekanisme transformasi oleh mikroorganisme dan oleh lingkungan abiotik. $^{1}$ Merkuri organik akan terdegradasi menjadi bentuk ion merkuri $\left(\mathrm{Hg}^{2+}\right)$ oleh enzim organomerkuri liase, dan selanjutnya $\left(\mathrm{Hg}^{2+}\right)$ akan didetoksifikasi oleh reduktase merkuri menjadi $\mathrm{Hg}$ yang mudah menguap. ${ }^{2}$

Banyak laporan menunjukkan bahwa habitat yang mengandung kontaminasi logam tingkat tinggi selama bertahun-tahun terus memiliki populasi dan aktivitas mikroba meskipun populasi dan aktivitas ini lebih rendah daripada habitat yang tidak terkontaminasi. Hal ini menunjukkan kondisi ekstrem yang dapat diadaptasi oleh mikroba ini, sehingga diasumsikan bahwa bakteri dapat hidup di lingkungan yang terkontaminasi merkuri dengan mekanisme pertahanan spesifiknya. ${ }^{3,4}$ Detoksifikasi atau bioremediasi bakteri terhadap merkuri merupakan bentuk mekanisme pertahanan bakteri melawan merkuri untuk tetap hidup.

Penggunaan bakteri tahan merkuri untuk mengatasi masalah pencemaran merkuri organik dan anorganik di lingkungan yang berpotensi sangat tinggi merupakan solusi yang menjanjikan. Dalam penelitian sebelumnya oleh Karamoy et al, ${ }^{5}$ ditemukan bakteri resisten merkuri anorganik yang dapat hidup pada media dengan konsentrasi $\mathrm{HgCl}_{2} 40 \mathrm{mg} /$ liter yang diisolasi dari urin pasien dengan tumpatan amalgam gigi, yaitu isolat Bacillus cereus isolat FUA yang disimpan dalam lemari pendingin di Laboratorium Mikrobiologi Departemen Farmasi Fakultas Matematika dan Ilmu Pengetahuan Alam Universitas Sam Ratulangi Manado. Dengan melihat berbagai ulasan dalam latar belakang maka penulis tertarik untuk menentukan aktivitas reduksi merkuri isolat Bacillus cereus isolat FUA pada berbagai media $\mathrm{pH}$ dan suhu inkubasi.

\section{METODE PENELITIAN}

Alat yang digunakan dalam penelitian ini ialah: sarung tangan steril, Erlenmeyer, gelas ukur, gelas kimia, tabung reaksi, rak tabung reaksi, pipet drop, timbangan analitik, batang pengaduk, cawan Petri, jarum ose, lampu spritus, tabung eppendorf, inkubator (Incucell), aliran udara laminar (Biotek), autoclave (ALP), mikropipet (Ecopipette), mikroskop (Olympus), kertas label, bungkus plastik, aluminium foil, kapas, kain kasa, dan CV-AAS.

Bahan yang digunakan dalam penelitian ialah sampel air, aquades, $\mathrm{NaCl}$, kaldu nutrisi, ekstrak ragi, tryptone, agar bakteriologis, metilen biru, metil merah, agar nutrien, agar sitrat Simmon, glukosa, laktosa, sukrosa, pereaksi Kovacs, fenil merkuri, merkuri, merkuri klorida $\left(\mathrm{HgCl}_{2}\right)$, hidrogen peroksida $\left(\mathrm{H}_{2} \mathrm{O}_{2}\right)$, asam sulfat $\left(\mathrm{H}_{2} \mathrm{SO}_{4}\right)$, alkohol $70 \%$.

Pada tahap pertama, uji morfologik dan fisiologik dilakukan pada koloni isolat FUA yang disimpan di laboratorium untuk membuktikan bahwa bakteri yang dianalisis ialah Bacillus yang resisten terhadap merkuri. Uji morfologik dilakukan dengan pewarnaan Gram; uji fisiologik dilakukan dengan menentukan ada tidaknya motilitas berdasarkan Talaro; ${ }^{6}$ uji biokimia yang dilakukan berdasarkan Lay yaitu uji $\mathrm{H}_{2} \mathrm{~S} ;{ }^{7}$ serta uji fermentasi karbohidrat, uji katalase, 
uji sitrat dan uji lisin dibuat berdasarkan Cappuccino \& Sherman. ${ }^{8}$ Selanjutnya, identifikasi dilakukan untuk melihat genus.

Penentuan pengaruh $\mathrm{pH}$ pada daya pengurangan merkuri FUA isolat yaitu dengan menggunakan 1 öse diambil bakteri resisten merkuri tinggi isolat FUA dari agar miring dan ditanam pada media kaldu nutrisi yang mengandung $10 \mathrm{mg} / \mathrm{l} \mathrm{HgCl}_{2}$ dengan

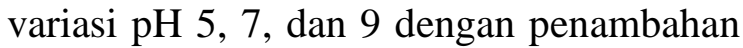
$0,1 \mathrm{~N} \mathrm{HCl}$ dan $0,1 \mathrm{~N} \mathrm{NaOH}$ dan diinkubasi pada suhu $37^{\circ} \mathrm{C}$ selama 24 jam. Pada akhir inkubasi, 2 tetes $\mathrm{H}_{2} \mathrm{SO}_{4}$ pekat ditambahkan untuk membunuh bakteri dan analisis merkuri lebih lanjut menggunakan metode analisis CVAAS dan analisis kosong dilakukan.

Penentuan pengaruh suhu terhadap daya pengurangan merkuri FUA isolat yaitu dengan menggunakan 1 öse diambil bakteri resisten merkuri tinggi dari media untuk dimiringkan, ditanam dalam media kaldu nutrisi yang mengandung $\mathrm{HgCl}_{2} 10 \mathrm{mg} / \mathrm{L}$, dan diinkubasi pada variasi suhu 15, 25 dan $35^{\circ} \mathrm{C}$ selama 24 jam. Pada akhir inkubasi, 2 tetes $\mathrm{H}_{2} \mathrm{SO}_{4}$ pekat ditambahkan untuk membunuh bakteri dan kemudian kadar merkuri dianalisis dengan metode analisis CVAAS dan analisis kosong dilakukan.

Penentuan konsentrasi merkuri dengan CV-AAS dilakukan dengan menambahkan $5 \mathrm{ml} \mathrm{KMnO} 4$ 6\% dan dibiarkan selama 15 menit. Kemudian $\mathrm{KMnO}_{4}$ ditambahkan lagi sampai warna permanganat terjadi selama 5 menit, dan akhirnya $5 \% \mathrm{~K}_{2} \mathrm{~S}_{2} \mathrm{O}_{8}$ ditambahkan dan dipindahkan dalam labu volumetrik. Campuran dibiarkan semalaman kemudian labu ditutup dengan teflon. Analisis dilakukan sesegera mungkin.

\section{HASIL PENELITIAN}

Bakteri resistensi merkuri dalam penelitian ini diperoleh dari urin pasien dengan restorasi amalgam merkuri. Sampel urin diperoleh dari 5 pasien di puskesmas Kota Manado. Terdapat satu koloni yang resistan terhadap merkuri tinggi pada $40 \mu \mathrm{g} / \mathrm{mL}$.

Berdasarkan hasil uji morfologik, fisiologik, dan biokimia, bakteri resisten merkuri tinggi tampak mengkilap pada media agar, berbentuk batang, Gram-positif, dan bakteri motil. Tabel 1 memperlihatkan hasil uji morfologik, fisiologik, dan biokimia yang menunjukkan adanya Bacillus spp.

Tabel 2 memperlihatkan hasil analisis kemampuan reduksi merkuri pada beberapa pH medium, yaitu $\mathrm{Ph} \mathrm{5,} \mathrm{6,} \mathrm{dan} \mathrm{7.} \mathrm{Selama}$ inkubasi 24 jam, kontrol negatif memiliki kadar $0 \% \mathrm{Hg}$ dan kontrol positif dengan kadar $\mathrm{Hg}$ tetap $100 \%$. Perlakuan isolat FUA dengan $\mathrm{pH}$ medium berbeda, menunjukkan perbedaan kadar $\mathrm{Hg}$ yaitu pada $\mathrm{pH} 5$ tetap $21,6 \%$, pH 7 tetap 20,2\%, dan pada $\mathrm{pH} 9$ tetap $21,5 \%$.

Tabel 1. Hasil uji morfologik, fisiologik, dan biokimia

\begin{tabular}{clcc}
\hline No & \multicolumn{1}{c}{ Uji } & Hasil & Identifikasi \\
\hline I & Morfologik & & \\
& - Pewarnaan Gram & $(+)$ & \\
& - Bentuk & basil & \\
II $\quad$ Fisiologik & & \\
& - Motilitas & Motil & Bacillus spp. \\
III & Biokimia & & \\
& - Citrat & - & \\
& - Indol & - & \\
& - Catalase & + & \\
& - Glucosa & + & \\
& - Sukrosa & - & \\
& - H & & \\
& - Lisin & - &
\end{tabular}


Tabel 2. Analisis hasil pengaruh $\mathrm{pH}$ pada kemampuan reduksi merkuri isolat FUA

\begin{tabular}{lcccc}
\hline \multirow{2}{*}{ Perlakuan } & \multicolumn{4}{c}{ Konsentrasi Hg (\%)/v) } \\
& Sebelum inkubasi & \multicolumn{2}{c}{ Setelah inkubasi 24 jam } \\
& & $\mathrm{pH} \mathrm{5}$ & $\mathrm{pH} \mathrm{7}$ & $\mathrm{pH} \mathrm{9}$ \\
\hline Kontrol (-) & 0 & 0 & 0 & 0 \\
Kontrol (+) & 100 & 100 & 100 & 100 \\
+ Isolat FUA & 100 & 21,6 & 20,2 & 21,5 \\
\hline
\end{tabular}

Tabel 3. Hasil analisis pengaruh suhu pada kemampuan reduksi merkuri isolat FUA

\begin{tabular}{lcccc}
\hline Perlakuan & \multicolumn{4}{c}{ Konsentrasi Hg (\%b/v) } \\
& Sebelum inkubasi & \multicolumn{2}{c}{ Setelah Inkubasi } & 24 jam \\
& & $15^{\circ} \mathrm{C}$ & $25^{\circ} \mathrm{C}$ & $35^{\circ} \mathrm{C}$ \\
\hline Kontrol (-) & 0 & 0 & 0 & 0 \\
Kontrol (+) & 100 & 100 & 100 & 100 \\
+ Isolat FUA & 100 & 35,4 & 22,7 & 20,7 \\
\hline
\end{tabular}

Hasil ini menunjukkan bahwa kekuatan reduksi merkuri yang kuat dari isolast FUA pada $\mathrm{pH} 7$ dapat mengurangi kadar merkuri terbesar yaitu 79,8\% dalam 24 jam.

Tabel 3 memperlihatkan hasil analisis kemampuan reduksi merkuri pada beberapa suhu inkubasi, yaitu $15^{\circ} \mathrm{C}, 25^{\circ} \mathrm{C}$, dan $35^{\circ} \mathrm{C}$. Isolat bakteri resisten merkuri dapat mengurangi kadar merkuri dalam merkuri anorganik selang waktu 24 jam pada suhu $15-35^{\circ} \mathrm{C}$.

\section{BAHASAN}

Berdasarkan hasil uji morfologik, fisiologik, dan biokimia, bakteri resisten merkuri tinggi tampak mengkilap pada media agar, yang berbentuk batang, Gram-positif, dan bakteri motil dengan hasil identifikasi yang diperoleh ialah Bacillus spp.

Secara umum, genus Bacillus adalah bakteri berbentuk batang (bacillus), dan bersifat Gram positif, umumnya aerob, dan membentuk endospor, hampir semua jenis basil bersifat motil, dan menghasilkan katalase. Berdasarkan identifikasi mikrobiologis, isolat bakteri resisten merkuri yang diperoleh termasuk dalam genus Bacillus. ${ }^{9}$

Uji sitrat dilakukan untuk melihat bakteri yang memiliki kemampuan menggunakan sitrat sebagai sumber karbon dan energi. Beberapa bakteri dapat menggunakan sitrat sebagai sumber energi jika tidak terdapat glukosa atau laktosa. Hal uni dapat terjadi jika bakteri memiliki enzim sitrat permease yang berperan dalam membawa sitrat dari luar sel ke dalam sel. Sitrat akan memasuki siklus Krebs dan hasilnya yaitu terbentuk asam piruvat dan karbon dioksida. Karbon dioksida bereaksi dengan air dan natrium yang terkandung dalam media Simmons sitrat sehingga membentuk natrium bikarbonat. Kehadiran natrium bikarbonat menyebabkan media menjadi basa sehingga warna indikator biru bromthymol berubah dari hijau menjadi biru. ${ }^{7,8}$

Pada uji indol, diperiksa apakah bakteri memiliki kemampuan untuk mendegradasi asam amino esensial triptofan yaitu asam amino yang dapat mengalami deaminasi dan hidrolisis oleh bakteri. Enzim yang berperan dalam proses ini ialah triptofanase. Produk metabolit triptofan ialah indol, asam piruvat, dan amonia. Kehadiran indol dideteksi oleh reagen Kovacs yang menyebabkan pembentukan warna merah pada permukaan media yang menunjukkan uji indol positif. Warna merah terjadi karena pembentukan kompleks antara indol dan p-metil amino benzaldehyde dari reagen Kovacs dalam kondisi asam. ${ }^{7,8}$

Sebagian besar bakteri menghasilkan enzim katalase yang dapat memecah $\mathrm{H}_{2} \mathrm{O}_{2}$ menjadi $\mathrm{H}_{2} \mathrm{O}$ dan $\mathrm{O} 2 .{ }^{7}$ Hidrogen peroksida beracun bagi sel karena bahan ini dapat 
mengaktifkan enzim dalam sel. Uji ini penting dilakukan untuk menentukan sifat bakteri terhadap kebutuhan oksigen.

Pada uji fermentasi karbohidrat, bakteri yang mampu memfermentasi glukosa akan membentuk warna kuning di bagian bawah media (butt), sedangkan bakteri yang mampu memfermentasi laktosa dan/atau sukrosa akan membentuk warna kuning pada kemiringan (slant).

Pada uji pembentukan $\mathrm{H}_{2} \mathrm{~S}$, hasil positif terlihat dengan adanya warna hitam di bagian bawah media dan hasil negatif jika tidak terbentuk warna hitam di bagian bawah media. ${ }^{7,8}$ Warna hitam terbentuk pada dasar media sebagai hasil reaksi dengan sulfida $\left(\mathrm{H}_{2} \mathrm{~S}\right)$. Kehadiran $\mathrm{H}_{2} \mathrm{~S}$ disebabkan oleh bakteri yang mengurangi metabolit sulfur dari natrium tiosulfat di media untuk menghasilkan hidrogen sulfida $\left(\mathrm{H}_{2} \mathrm{~S}\right)$. Ion $\mathrm{S}^{2-}$ yang diproduksi oleh bakteri bereaksi dengan ion $\mathrm{Fe}^{3+}$ untuk membentuk $\mathrm{Fe}_{2} \mathrm{~S}_{3}$ dalam bentuk endapan hitam. Sulfat merupakan sumber energi anorganik untuk bakteri. Bakteri yang tidak mampu mengurangi sulfur tidak akan menghasilkan $\mathrm{H}_{2} \mathrm{~S}$ sehingga warna hitam tidak terbentuk pada media.

Deaminasi lisin ialah proses aerobik yang terjadi pada media miring, sedangkan dekarboksilasi lisin ialah proses anaerob yang terjadi pada media butt. Hasil positif dari dekarboksilasi ditunjukkan oleh warna ungu pada media butt. Hasil negatif ditunjukkan dengan warna kuning kecoklatan pada media butt. ${ }^{10}$ Hasil identifikasi mikrobiologis memperlihatkan bahwa bakteri isolat FUA menunjukkan karakteristik yang menyerupai genus Bacillus sp. Hasil ini konsisten dengan penelitian oleh Parvin et al $^{11}$ yang mendapatkan bahwa bakteri yang diisolasi dari urin aliran tengah manusia ialah Escherichia coli, Staphylococcus spp., dan Bacillus spp. ${ }^{12}$ Chrostofel et al (2017) mengisolasi jenis bakteri resisten merkuri dari plak gigi pasien, salah satunya ialah bakteri Bacillus thuringiensis. ${ }^{13}$

Bacillus adalah bakteri anaerob Grampositif, aerob atau fakultatif, berbentuk batang, dan chemoorganotrophic. ${ }^{13}$ Narita et al melaporkan bahwa 21 dari 56 spesies Bacillus yang diisolasi dari 15 tempat berbeda di dunia memiliki transposon yang menyerupai TnMERI1, yang kemudian diklasifikasikan menjadi Tn5084, Tn5085, dan TnMERI. Hal ini mungkin berkontribusi pada penyebaran horizontal operon antara Bacillus. ${ }^{13,14}$ TnMER/1 termasuk transposon kelas II yang memiliki gen tahan merkuri spektrum luas. ${ }^{13}$ Zulaika et al ${ }^{15}$ melaporkan bahwa beberapa Bacillus yang diisolasi di Surabaya, Indonesia, tahan terhadap merkuri pada konsentrasi $25 \mathrm{mg} / \mathrm{L}$ $\mathrm{HgCl}_{2}$.

Tabel 1 memperlihatkan bahwa selama inkubasi 24 jam, kontrol negatif memiliki kadar $0 \% \mathrm{Hg}$, kontrol positif dengan kadar Hg tetap $100 \%$, sedangkan pada perlakuan isolat FUA dengan $\mathrm{pH}$ medium berbeda menunjukkan perbedaan kadar $\mathrm{Hg}$ yaitu pada $\mathrm{pH} 5$ tetap 21,6\%, pH 7 tetap 20,2\%, dan pada $\mathrm{pH} 9$ tetap 21,5\%. Hasil ini menunjukkan bahwa kekuatan reduksi merkuri yang kuat dari isolat FUA pada $\mathrm{pH}$ 7 dapat mengurangi kadar merkuri terbesar yaitu 79,8\% dalam 24 jam. Rentang untuk pertumbuhan bakteri pada $\mathrm{pH}$ 5,7-pH 7,0. Selain itu, nilai $\mathrm{pH}$ optimal ialah $\mathrm{pH}$ netral, yang memfasilitasi enzim merkuri reduktase untuk mengurangi merkuri. Sel-sel bakteri mulai membelah ketika mereka menyesuaikan diri dengan lingkungannya dan fase ini disebut fase log. Pada fase log, sel-sel bakteri memulai pembagian reguler dengan pembelahan biner. ${ }^{16}$ Selama fase log, faktor lingkungan seperti $\mathrm{pH}$ dan suhu penting untuk mendukung pertumbuhan bakteri. ${ }^{17}$ Sel bakteri terus tumbuh sampai mencapai jumlah sel tetap konstan. Fase ketiga ini disebut fase stasioner. Hasil yang diperoleh ialah kekuatan reduksi merkuri isolate FUA konsisten dengan kondisi optimum untuk pertumbuhan bakteri pada $\mathrm{pH}$ netral. Menurut Vetriani et al, ${ }^{18}$ bakteri resisten merkuri tinggi mengandung pengkodean merOperon flavoenzim merkuri reduktase yang dapat mengurangi ion $\mathrm{Hg}^{2+}$ menjadi $\mathrm{Hg} 0$ yang kurang toksik.

Hasil analisis pada Tabel 2, menunjukkan bahwa isolat bakteri resisten merkuri dapat mengurangi kadar merkuri dalam merkuri anorganik dalam waktu 24 jam pada suhu $15-35^{\circ} \mathrm{C}$. Pada pengaruh suhu, persen- 
tase merkuri anorganik $\left(\mathrm{HgCl}_{2}\right)$ yang tersisa selama 24 jam inkubasi ialah $15^{\circ} \mathrm{C}=35,4 \%$; $25^{\circ} \mathrm{C}=22,7 \%$; dan $35^{\circ} \mathrm{C}=20,7 \%$, sehingga dapat dikatakan bahwa suhu memengaruhi daya reduksi merkuri dari isolat FUA Bacillus cereus karena dapat mengurangi kadar merkuri sebesar 79,3\% dalam waktu 24 jam pada $35^{\circ} \mathrm{C}$. Prescott et al ${ }^{19}$ mengemukakan bahwa pengaruh suhu pada pertumbuhan mikroba ialah karena sensitivitas reaksi yang dikatalisis oleh enzim. Pada suhu rendah, pertumbuhan akan meningkat dua kali lipat, dengan meningkatnya suhu dan laju reaksi akan meningkat

Enzim yang terlibat dalam proses mengurangi merkuri oleh bakteri ialah merkuri reduktase. ${ }^{20,21}$ Hasil penelitian ini memperlihatkan bahwa semakin tinggi suhu semakin rendah kadar merkuri di media, yang menunjukkan semakin tinggi kadar merkuri berkurang oleh enzim merkuri reduktase yang terkandung dalam bakteri isolat FUA. Selain enzim merkuri reduktase yang terlibat dalam proses detoksifikasi merkuri oleh bakteri, terdapat juga enzim liase organomerkuri yang memutus ikatan merkuri organik dengan bakteri tahan merkuri. ${ }^{22}$

Terdapat tiga mekanisme respons terhadap merkuri, yaitu: 1) menghambat metabolisme sel sehingga pertumbuhan sel melambat atau sel mati; 2) menginduksi sistem operon yang tahan merkuri agar bekerja sehingga sel tetap hidup bahkan di bawah kondisi yang menekan; dan 3) plasmid yang mengandung gen tahan merkuri masuk ke dalam sel. Isolat bakteri yang dapat hidup pada media dengan kadar merkuri $10 \mathrm{mg} / \mathrm{L}, 20 \mathrm{mg} / \mathrm{L}$ dan $40 \mathrm{mg} / \mathrm{L}$ dapat menggunakan mekanisme respons kedua atau bahkan ketiga sehingga bakteri dapat hidup pada media dengan kadar merkuri yang tinggi. Faktor lain yang memengaruhi penurunan konsentrasi merkuri dalam kultur ialah perbedaan jumlah sel bakteri yang tumbuh di media, yang dapat disebabkan oleh perbedaan kondisi partumbuhan optimal seperti $\mathrm{pH}$ dan suhu dari setiap jenis bakteri. $^{21}$

\section{SIMPULAN}

Daya reduksi merkuri dari Bacillus cereus isolat FUA dipengaruhi oleh $\mathrm{pH}$ media dan suhu inkubasi, yaitu daya reduksi merkuri optimal pada media dengan $\mathrm{pH} 7$ dan suhu inkubasi $35^{\circ} \mathrm{C}$.

Disarankan untuk penggunaan Bacillus cereus isolat FUA pada proses detoksifikasi merkuri dalam lingkungan.

\section{Pernyataan Terima Kasih}

Penelitian ini dibiayai oleh DIPA Universitas Sam Ratulangi Kementerian Riset, Teknologi, dan Pendidikan Tinggi, Republik Indonesia, melalui Universitas Sam Ratulangi dengan skema penelitian unggulan (RTUU) tahun fiskal 2018.

\section{Konflik Kepentingan}

Penulis menyatakan tidak terdapat konflik kepentingan dalam studi ini.

\section{DAFTAR PUSTAKA}

1. Barkay T, Wagner-Dobler I. Microbial transformation of mercury: potentials, challenges, and achievements in controlling mercury toxicity in the environment. Advances in Applied Microbiology. New Jersey: Department of Biochemistry and Microbiology Cook College, Rutgers University New Brunswick, 2005.

2. Gupta A, Phung LT, Chakravarty L, Silver S. Mercury resistance in Bacillus cereus RC607: Transcriptional organization and two new open reading frames. J Bacteriol. 1999;181(22):7080-6.

3. Konopta A, Zakharova T, LaPara TM. Bacterial function and community structure in reactors treating biopolymers and surfactants at mesophilic and thermophilic temperatures. J Ind Microbiol Biot. 1999;23:127-32.

4. Summers AO. Metal resistence loci of bacterial plasmids: a tribute to Stuart B. Levy. In: White DG, Alekshun MN, McDermott $\mathrm{PF}$, editors. Frontier in Antimicrobial Resistence. Washington DC: American Society for Microbiology, 2005.

5. Karamoy ME, Fatimawali, Kepel BJ. Isolasi dan identifikasi bakteri resisten merkuri melalui analisis gen 16SrRna pada urin pasien dengan tumpatan amalgam. 
eBiomedik. 2017;5(2).

6. Talaro KP. Foundations in Microbiology (7th ed). McGraw-Hill Higher Education, 2008.

7. Lay BW. Analisis Mikroba di Laboratorium. Jakarta: PT Raja Grafindo Persada, 1994; p. 168.

8. Cappuccino JG, Sherman N. Microbiology: A Laboratory Manual (3rd ed). California: Benjamin/Cummings Publishing Company, 1992.

9. Holt JG, Krieg NR, Piter HAS, Eilliama JT. Bergeys Manual of Determinative Bacteriolog (9th ed). Baltimore: Lippincott William and Wilkins, 1994.

10. Mac Faddin JF. Biochemical Tests for Identification of Medical Bacteria. Lippincott Williams \& Wilkins, 2000.

11. Parvin K, Rahman N, Rahman MM, Islam MA. Isolation and characterization of microflora from human urine. Microbes and Health. 2013;2(1):15-8

12. Mandic-Mulec I, Stefanic P, van Elsas JD. Ecology of Bacillaceae. Microbiol Spectr. 2015;3(2):TBS-0017-2013.

13. Narita M, Matsui K, Huang CC, Kawabata Z, Endo G. Dissemination of TnMERI-like mercury resistance transposons among Bacillus isolated from worldwide environmental samples. FEMS Microbiol Ecol. 2004;48(1):47-55.

14. Matsui K, Yoshinami S, Narita M, Chien MF, Phung le T, Silver S, Endo G. Mercury resistance transposons in Bacilli strains from different geographical regions.
FEMS Microbiol Lett. 2016;363(5): fnw013.

15. Zulaika E, Sembiring L, Soegianto A. Characterization and identification of mercury-resistant bacteria from Kalimas River Surabaya-Indonesia by numerical phenetic taxonomy. JBASR. 2012;2(7): 7263-9.

16. Koni TNI, Rusman, Hanim C, Zuprizal. Effect of $\mathrm{pH}$ and temperature on Bacillus subtilis FNCC 0059 oxalate decarboxylase activity. Pakistan Journal of Biological Sciences. 2017;20:436-41.

17. Tanner A, Borneman S. Bacillus subtilis YvrK is an acid-induced oxalate decarboxylase. J Bacteriol. 2000;182(18):5271-3.

18. Vetriani C, Chew YS, Miller SM, Yagi J, Coombs J, Lutz RA, Barkay T. 2005. Mercury adaptation among bacteria from a deep-sea hydrothernmal vent. Appl Environ Microb. 2005;71(1):2206.

19. Prescott LM, Harley JP, Klein DA. Microbiology (4th ed). New York: McGraw-Hill, 1999; p. 55-90.

20. Fatimawali, Kepel BJ, Tallei TE. Overproduction of mercuric reductase protein expressed by syntetic merA gene and reduction of inorganic mercury $\mathrm{HgCl} 2$. Biosci Res. 2017;14:1253-60.

21. Fatimawali, Kepel BJ, Tallei TE. Potential of organic mercury-resistant bacteria isolated from mercury contaminated sites for organic mercury remediation. Pak J Biol Sci. 2019;22(1):45-50. 